\title{
Respons dua generasi tomat mutan insensitif etilen Sletr1-2 terhadap cekaman kekeringan
}

Sari Buah tomat tergolong kedalam golongan buah klimaterik. Umur simpan buah tomat sangat dipengaruhi oleh keberadaan etilen. Tomat mutan NIL Sletr1-2 adalah generasi baru dari tomat insensitifetilen.Buah dari tomat mutan NIL Sletr1-2 memiliki umur simpan yang lebih lama dari tomat komersial pada umumnya namun kehilangan fungsi untuk merespon keberadaan etilen dapat berpengaruh kepada pertumbuhan dan perkembangan tanaman, khususnya dalam kondisi cekaman. Tujuan dari penelitian ini adalah untuk mengetahui efek cekaman kekeringan terhadap dua generasi tomat mutan insensitif etilen (NIL Sletr1-2 dan $\mathrm{BC}_{3} \mathrm{~F}_{1}$ Sletr1-2), dengan tomat 'Intan' sebagai tanaman kontrol. Ketiga tomat tersebut disiram dengan tiga interval waktu yang berbeda, yaitu: setiap hari (kondisi normal), interval tiga hari (cekaman kekeringan moderat), dan interval lima hari (cekaman kekeringan berat). Hasil penelitian menunjukkan bahwa dalam kondisi cekaman kekeringan moderat dan berat, respons morfologis (tinggi tanaman, jumlah daun, dan panjang akar), dan anatomis (jumlah sel epidermis) kedua generasi tomat mutan lebih buruk dari tetuanya tomat 'Intan'. Hal tersebut menunjukkan bahwa berkurangnya sensitivitas etilen meningkatkan kerentanan tanaman dalam kondisi cekaman kekeringan, sekaligus memperkuat anggapan bahwa etilen berperan penting dalam ketahanan tanaman terhadap cekaman lingkungan.

Kata kunci: Cekaman kekeringan · Etilen · Insensitivitas etilen · Tomat mutan

\section{Response of two mutant tomatoes (Sletr1-2) generations under drought stress}

\begin{abstract}
Tomato belongs to climacteric fruits, Its fruit shelf life is highly affected by the presence of ethylene. NIL Sletr1-2 tomato is a novel generation of an ethylene insensitive mutant. Its fruit has prolonged fruit shelf life, lasting longer than commercial ones. However, the loss of function in ethylene response would affect plant growth and development, especially under stress conditions. The objective of this research was to investigate the effect of drought stress on two generations of ethylene insensitive tomato mutants (NIL Sletr1-2 and $\mathrm{BC}_{3} \mathrm{~F}_{1}$ Sletr1-2), with 'Intan' as a control plant. Those tomatoes were watered at three different intervals:every day; three days interval; and five days. The results showed that under three and five days watering interval, both generation of ethylene insensitive mutants have reduction in plant morphological response (plant height, number of leaves, and root length) and anatomical response (epidermal cell count), compared to their control, 'Intan'. These results indicated that reduction in ethylene sensitivity could increase plant susceptibility under drought stress condition, thus solidifying the importance of ethylene in plant defence against environmental stress.
\end{abstract}

Keywords: Drought stress $\cdot$ Ethylene $\cdot$ Ethylene receptor $\cdot$ Tomato mutant

Diterima : 1 Februari 2021, Disetujui : 7 April 2021, Dipublikasikan : 16 April 2021 doi: https:// doi.org/10.24198/kultivasi.v20i1.32034

\footnotetext{
Rahmat, B.P.N. ${ }^{1}$ N. Wicaksana ${ }^{1}$ S. Mubarok ${ }^{2}$ M.J. Ramadhan ${ }^{2}$ M.Z. Putri ${ }^{2}$. H. Ezura ${ }^{3}$

${ }^{1}$ Prodi Agroteknologi, Fakultas Pertanian Universitas Padjadjaran

2Prodi Agroteknopreneur, Fakultas Pertanian Universitas Padjadjaran

${ }^{3}$ Faculty of Life and Environmental Sciences, University of Tsukuba, Japan

Korespondensi: syariful.mubarok@unpad.ac.id
} 


\section{Pendahuluan}

Tanaman tomat merupakan tanaman komersial penting bagi perekonomian berbagai Negara, seperti New Zealand, Malawi, dan China (Kamanga et al., 2018). Permintaan tomat di pasar Indonesia terus meningkat setiap tahunnya. Badan Pusat Statistika Indonesia memprediksi kenaikan permintaan pasar akan buah tomat sebesar 5,32\% setiap tahunnya, dimulai dari tahun 2017 hingga tahun 2021 (Pusat Pengkajian Perdagangan Dalam Negeri, 2019). Oleh karena itu, produktivitas dan indeks pertanaman tomat perlu ditingkatkan.

Kekeringan merupakan salah satu faktor utama yang mengurangi produktivitas tanaman di dunia (Mishra et al., 2012). Stress akibat kekurangan air menyebabkan terjadinya alterasi pada karakteristik fisiologis, biokimia, kimia, dan morfologis tanaman (Aguirrezabal et al., 2006; Mishra et al., 2012). Tanaman tomat tergolong ke dalam tanaman yang rentan akan kekeringan dan hasil panennya sangat bergantung kepada ketersediaan air (Yuan et al., 2016). Hal tersebut disebabkan tanaman tomat membutuhkan jumlah air yang banyak agar dapat tumbuh dengan baik (Klunklin and Savage, 2017). Menurut Cahyono (1998) tanaman tomat membutuhkan 400-600 mL air setiap harinya untuk terus tumbuh, dengan total air yang dibutuhkan sebesar $100.000 \mathrm{~L} /$ tanaman.

Buah tomat termasuk ke dalam golongan buah klimakterik sehingga umur simpannya sangat dipengaruhi oleh keberadaan hormon etilen (Balaguera-Lopez et al., 2015). Salah satu cara untuk memperpanjang umur simpan tanaman tomat adalah melalui perakitan varietas baru menggunakan teknologi mutasi (Ningrumet al., 2020). Meskipun etilen dapat memperpendek umur simpan buah, etilen berperan penting dalam ketahanan tanaman dalam kondisi cekaman abiotik. Menurut Jung et al. (2009) beragam respons stress yang diatur oleh hormon etilen sangat berpengaruh terhadap kemampuan tanaman untuk bertahan hidup pada kondisi stress. Glick et al. (2007) melaporkan bahwa etilen berperan sebagai aktivator sistem pertahanan tanaman.Etilen juga berperan dalam produksi hormon antioksidan (Kamanga et. al., 2018). Sehingga tanaman yang respons etilennya terganggu akan kesulitan untuk bertahan dalam kondisi tercekam (Jung et.al., 2009).
Tomat mutan Sletr1-2 merupakan tomat mutan yang insensitif terhadap hormon etilen sehingga masa simpan buahnya lebih lama dibandingkan dengan tomat umumnya. Penelitian Okabe et al. (2011) menunjukkan bahwa buah yang dihasilkan tomat mutan Sletr1-2 dapat di simpan selama 30 hari lebih lama dibandingkan dengan tomat komersial yang digunakan sebagai kontrol. Insensitivitas terhadap etilen pada tomat mutan Sletr1-2 diakibatkan oleh terjadinya mutasi pada posisi kedua dari transmembran reseptor etilen yaitu adanya perubahan asam amino pada P51 yang tersubtitusi menjadi L (Okabe et al., 2011). Namun demikian, tanaman tomat mutan Sletr12 belum diketahui responsnya terhadap kekeringan sehingga perlu diteliti.

\section{Bahan dan Metode}

Penanaman dilakukan didalam screenhouse yang berlokasi di Kebun Hidroponik Universitas Padjajaran, Kecamatan Jatinangor, Kabupaten Sumedang, Jawa Barat. Rancangan penelitian yang dilakukan yaitu rancangan acak kelompok faktorial yang terdiri dari 2 taraf dengan 3 ulangan. Sebagai taraf pertama yaitu kultivar tomat,yaitu tomat Intan (sebagai kontrol), serta dua varietas insensitif etilen: $\mathrm{BC}_{3} \mathrm{~F}_{1}$ Sletr1-2 dan NILSletr1-2.

Perlakuan penyiraman yang dilakukan yaitu penyiraman setiap hari, 100\% kapasitas lapang (kontrol), penyiraman dengan interval 3 hari (51\% kapasitas lapang), dan penyiraman dengan interval 5 hari (12\% kapasitas lapang). Penelitian dilakukan pada bulan September hingga bulan Oktober 2020. Perlakuan penyiraman dimulai ketika tanaman berusia 3 minggu setelah tanam (MST) dan berlangsung selama 15 hari.Sebelum tanaman berusia 3 MST tanaman disiram setiap hari.Benih tomat mutan NIL Sletr1-2, $\mathrm{BC}_{3} \mathrm{~F}_{1}$ Sletr1-2, dan Intan disemai terlebih dahulu selama 14 hari. Pindah tanam dilakukan pada polybag berdiameter $50 \mathrm{~cm}$ yang diisi oleh campuran media tanam cocopeat, arang sekam, dan pupuk kandang dengan perbandingan 1:1:1.

Analisis data respon morfologis dan anatomis dilakukan menggunakan software pengolah data SPSS 26. Uji lanjut yang digunakan adalah uji Tukey-HSD pada taraf nyata $5 \%$. 


\section{Hasil dan Pembahasan}

Tinggi Tanaman. Hasil analisis tinggi tanaman pada 15 hari setelah perlakuan (HSP) menunjukkan bahwa interaksi antara kultivar dan interval penyiraman menimbulkan perbedaan yang nyata pada tinggi tanaman (Tabel 1). Cekaman kekeringan menyebabkan berkurangnya laju pertambahan tinggi pada semua tomat uji. Pertambahan tinggi tanaman tomat mutan NIL Sletr1-2 sangat dipengaruhi oleh cekaman kekeringan, sehingga pada interval penyiraman 3 hari dan 5 hari nilai pertambahan tinggi dari tomat mutan NIL Sletr1-2 berbeda nyata dengan kultivar lainnya.

Tabel 1. Respons pertambahan tinggi tanaman (cm) tiga kultivar tomat terhadap cekaman kekeringan pada 15 HSP.

\begin{tabular}{lccc}
\hline \multirow{2}{*}{ Kultivar } & \multicolumn{3}{c}{ Interval Penyiraman } \\
\cline { 2 - 4 } & $\mathbf{1}$ & $\mathbf{3}$ & $\mathbf{5}$ \\
\hline Intan & $6,05 \mathrm{a}$ & $6,38 \mathrm{~b}$ & $5,84 \mathrm{~b}$ \\
& $\mathrm{AB}$ & $\mathrm{B}$ & $\mathrm{A}$ \\
\hline $\mathrm{BC}_{3} \mathrm{~F}_{1}$ & $7,83 \mathrm{~b}$ & $6,05 \mathrm{~b}$ & $5,12 \mathrm{~b}$ \\
Sletr $1-2$ & $\mathrm{C}$ & $\mathrm{B}$ & $\mathrm{A}$ \\
\hline NIL & $5,89 \mathrm{a}$ & $4,44 \mathrm{a}$ & $3,61 \mathrm{a}$ \\
Sletr1-2 & $\mathrm{C}$ & $\mathrm{B}$ & $\mathrm{A}$ \\
\hline
\end{tabular}

Keterangan; Angka yang diikuti huruf yang sama tidak berbeda nyata menurut uji lanjut Tukey-HSD pada taraf nyata 5\%. Huruf kecil dibaca arah horizontal (baris) dan huruf kapital di baca arah vertikal (kolom).

Terhambatnya laju pertambahan tinggi tanaman pada kondisi kekeringan diakibatkan oleh penurunan tekanan turgor yang membatasi pembesaran dan mengurangi ukuran sel (Steuter, 1981; Ningrum et al., 2020). Rendahnya nilai pertambahan tinggi tanaman tomat mutan Sletr1-2 dalam kondisi cekaman kekeringan diakibatkan oleh pertumbuhan daun (Tabel 2), dan akar yang terhambat (Tabel 3), sehingga tomat mutan Sletr1-2 terganggu kemampuan berfotosintesisnya. Jumawati et al. (2014) menyatakan bahwa tanaman yang fotosintesisnya terganggu maka pertumbuhannya akan terhambat.

Jumlah Daun. Pengaturan interval penyiraman yang dilakukan selama 15 hari menunjukkan adanya perbedaan nyata dalam jumlah daun yang dimiliki masing-masing tanaman (Tabel 2). Tanaman yang berada dalam cekaman kekeringan memiliki rata-rata jumlah daun yang lebih sedikit. Hussain et al. (2016) menyatakan bahwa salah satu respons tanaman yang berada dalam cekaman kekeringan adalah pembatasan pembentukan daun.

Tabel 2. Respons jumlah daun tanaman tiga kultivar tomat terhadap cekaman kekeringan pada 15 HSP.

\begin{tabular}{lccc}
\hline \multirow{2}{*}{ Kultivar } & \multicolumn{3}{c}{ Interval Penyiraman } \\
\cline { 2 - 4 } & $\mathbf{1}$ & $\mathbf{3}$ & $\mathbf{5}$ \\
\hline Intan & $31 \mathrm{a}$ & $31 \mathrm{c}$ & $29,67 \mathrm{c}$ \\
& $\mathrm{B}$ & $\mathrm{B}$ & $\mathrm{A}$ \\
\hline $\mathrm{BC}_{3} \mathrm{~F}_{1}$ Sletr & $30,33 \mathrm{~b}$ & $29,33 \mathrm{~b}$ & $26,33 \mathrm{~b}$ \\
$1-2$ & $\mathrm{C}$ & $\mathrm{B}$ & $\mathrm{A}$ \\
\hline NIL Sletr1- & $30,33 \mathrm{a}$ & $26,33 \mathrm{a}$ & $25 \mathrm{a}$ \\
2 & $\mathrm{C}$ & $\mathrm{B}$ & $\mathrm{A}$ \\
\hline
\end{tabular}

Keterangan; Angka yang diikuti huruf yang sama tidak berbeda nyata menurut uji lanjut Tukey-HSD pada taraf nyata 5\%. Huruf kecil dibaca arah horizontal (baris) dan huruf kapital di baca arah vertikal (kolom).

Jumlah daun tomat mutan NIL Sletr1-2 dan $\mathrm{BC}_{3} \mathrm{~F}_{1}$ Sletr1-2 lebih sedikit dibandingkan dengan tomat Intan pada kondisi cekaman kekeringan. Hal tersebut disebabkan oleh pertumbuhan akar kedua tomat mutan yang terhambat (Tabel 3) dan akibat kematian sel yang terjadi pada bagian daun tanaman yang disebabkan oleh akumulasi ROS (Reactive Oxygen Species) pada jaringan tanaman (Poóret al., 2015). Alves et al. (2017) melaporkan hasil penelitian yang serupa, daun tanaman tomat mutan insensitif etilen lainnya, yaitu tomat mutan Never ripe (Nr) mengandung lebih banyak senyawa ROS dibandingkan dengan Wild type-nya. Terhambatnya pertumbuhan akar menyebabkan terjadinya defisiensi hara (Babu et al., 2012), sementara kematian sel pada bagian daun mengurangi kemampuan tanaman untuk berfotosintesis (Alves et al., 2017).

Panjang akar. Hasil analisis panjang akar setelah 15 HSP menunjukkan adanya interaksi antara kultivar dengan interval penyiraman yang menyebabkan timbulnya perbedaan nyata pada nilai panjang akar tanaman (Tabel 3). Tanaman yang berada dalam kondisi tercekam oleh kekeringan memiliki panjang akar yang lebih pendek dibandingkan dengan tanaman yang tumbuh dalam kondisi normal. Pertumbuhan dan perkembangan akar merupakan salah satu karakter morfologi dan fisiologi yang terkait dengan sifat toleran terhadap cekaman 
kekeringan (Bohn et al., 2006). Perpanjangan akar dalam kondisi tercekam merupakan ciri dari tanaman yang toleran.Akar yang panjang mempermudah penyerapan air dalam kondisi cekaman (Kulkarni \& Deshpande, 2007).

Tabel 3. Respons panjang akar tanaman (cm) tiga kultivar tomat terhadap cekaman kekeringan pada 15 HSP.

\begin{tabular}{lccc}
\hline \multirow{2}{*}{ Kultivar } & \multicolumn{3}{c}{ Interval Penyiraman } \\
\cline { 2 - 4 } & 1 & 3 & 5 \\
\hline Intan & $20,67 \mathrm{~b}$ & $20,67 \mathrm{c}$ & $19,67 \mathrm{c}$ \\
& $\mathrm{B}$ & $\mathrm{B}$ & $\mathrm{A}$ \\
\hline $\mathrm{BC}_{3} \mathrm{~F}_{1}$ Sletr & $21,33 \mathrm{~b}$ & $19,67 \mathrm{~b}$ & $15,67 \mathrm{~b}$ \\
$1-2$ & $\mathrm{~B}$ & $\mathrm{~B}$ & $\mathrm{~A}$ \\
\hline NIL Sletr1- & $19,67 \mathrm{a}$ & $12,33 \mathrm{a}$ & $9,67 \mathrm{a}$ \\
2 & $\mathrm{C}$ & $\mathrm{B}$ & $\mathrm{A}$ \\
\hline
\end{tabular}

Keterangan; Angka yang diikuti huruf yang sama tidak berbeda nyata menurut uji lanjut Tukey-HSD pada taraf nyata 5\%. Huruf kecil dibaca arah horizontal (baris) dan huruf kapital di baca arah vertikal (kolom).

Tanaman tomat mutan NIL Sletr1-2 dan BC3F1 Sletr1-2 memiliki panjang akar yang lebih pendek dari tomat Intan pada kondisi cekaman kekeringan moderat ataupun berat (Tabel 3). Hal tersebut disebabkan oleh terinisiasinya PCD (Programmed Cell Death) pada bagian jaringan apikal akar akibat $\mathrm{O}_{2}^{-}$yang berikatan dengan NO (Chmielowska-Bąk et al., 2014). Poór et al. (2015) melaporkan hal yang serupa dengan hasil penelitian ini, PCD terinisasi pada jaringan apikal akar tanaman tomat mutan insensitif etilen $\mathrm{Nr}$ lebih awal dari Wild type-nya, sehingga pertumbuhan akarnya terhambat lebih awal.

Jumlah sel epidermis. Hasil analisis jumlah sel epidermis setelah 15 HSP menunjukkan adanya interaksi antara kultivar dengan interval penyiraman yang menyebabkan timbulnya perbedaan nyata pada nilai jumlah sel epidermis (Tabel 4).

Tanaman yang berada dalam kondisi tercekam oleh kekeringan memiliki jumlah sel epidermis yang lebih banyak. Menurut Bosabalidis \& Kofidis (2002), hal tersebut merupakan bentuk adapatasi tanaman terhadap kondisi lingkungannya. Jumlah sel epidermis pada daun tanaman tomat mutan NIL Sletr1-2 dan $\mathrm{BC}_{3} \mathrm{~F}_{1}$ Sletr1-2 lebih tinggi dibandingkan dengan jumlah sel epidermis pada daun tomat
Intan. Menurut Skirycz et al. (2011) etilen berperan dalam pemberhentian proliferasi sel epidermis daun dalam kondisi cekaman. Insensitivitas etilen menyebabkan sel epidermis tomat mutan NIL Sletr1-2 dan $\mathrm{BC}_{3} \mathrm{~F}_{1}$ Sletr1-2 dapat terus berproliferasi pada kondisi cekaman kekeringan (Tabel 4).

Tabel 4. Respons jumlah sel tiga kultivar tomat terhadap cekaman kekeringan pada 15 HSP.

\begin{tabular}{lccc}
\hline \multirow{2}{*}{ Kultivar } & \multicolumn{3}{c}{ Interval Penyiraman } \\
\cline { 2 - 4 } & 1 & 3 & 5 \\
\hline Intan & $740 \mathrm{~b}$ & $896 \mathrm{c}$ & $1008 \mathrm{c}$ \\
& $\mathrm{B}$ & $\mathrm{B}$ & $\mathrm{A}$ \\
\hline $\mathrm{BC}_{3} \mathrm{~F}_{1}$ & $614 \mathrm{~b}$ & $913 \mathrm{~b}$ & $1181 \mathrm{~b}$ \\
Sletr $1-2$ & $\mathrm{~B}$ & $\mathrm{~B}$ & $\mathrm{~A}$ \\
\hline NIL & $646 \mathrm{a}$ & $1024 \mathrm{a}$ & $1291 \mathrm{a}$ \\
Sletr1-2 & $\mathrm{C}$ & $\mathrm{B}$ & $\mathrm{A}$ \\
\hline
\end{tabular}

Keterangan; Angka yang diikuti huruf yang sama tidak berbeda nyata menurut uji lanjut Tukey-HSD pada taraf nyata 5\%. Huruf kecil dibaca arah horizontal (baris) dan huruf kapital di baca arah vertikal (kolom).

Namun, pertumbuhan dan pembelahan sel yang terus terjadi pada kondisi cekaman, dapat berdampak buruk terhadap survivabilitas tanaman dalam kondisi tercekam. Tanaman arabidopsis mutan insensitif etilen ein 2,5 dan etr 1,3 memiliki jumlah dan ukuran sel epidermis yang lebih besar dari kontrol di awal cekaman, namun pertumbuhannya menjadi lebih buruk dibandingkan Wild-type-nya setelah 22 hari tercekam kekeringan (Skirycz et al. 2010).

\section{Kesimpulan}

Berdasarkan hasil penelitian yang didapat maka dapat disimpulkan bahwa :

1. Adanya interaksi antara kultivar dan interval penyiraman yang berpengaruh terhadap respons morfologis dan anatomis tanaman tomat mutan insensitif etilen NIL Sletr1-2, $\mathrm{BC}_{3} \mathrm{~F}_{1}$ Sletr1-2, dan tomat Intan.

2. Tanaman tomat mutan NI Sletr1-2 sangat rentan terhadap cekaman kekeringan.

3. Tanaman tomat mutan NI Sletr1-2memiliki toleransi terhadap cekaman kekeringan seperti kontrol, kecuali pada parameter tinggi tanaman dan jumlah daun. 


\section{Daftar Pustaka}

Aguirrezabal, L., Bouchier- Combaud, S., Radziejwoski, A., Dauzat, M., Cookson, S. J., \& Granier, C. 2006. Plasticity to soil water deficit in Arabidopsis thaliana: dissection of leaf development into underlying growth dynamic and cellular variables reveals invisible phenotypes. Plant, Cell E Environment, 29(12), 2216-2227.

Alves, L. R., Monteiro, C. C., Carvalho, R. F., Ribeiro, P. C., Tezotto, T., Azevedo, R. A., \& Gratão, P. L. 2017. Cadmium stress related to root-to-shoot communication depends on ethylene and auxin in tomato plants. Environmental and Experimental Botany, 134, 102-115.

Babu, M. A., Singh, D., \& Gothandam, K. M. 2012. The effect of salinity on growth, hormones and mineral elements in leaf and fruit of tomato cultivar PKM1. J Anim Plant Sci, 22(1), 159-164.

Balaguera-López, H. E., Martínez, C. A., \& Herrera A, A. 2015. Refrigeration affects the postharvest behavior of 1-methylcyclopropenetreated cape gooseberry (Physalis peruviana L.) fruits with the calyx. Agronomía Colombiana, 33(3), 356-364.

Bohn, M., J. Novais, R. Fonseca, R. Tuberosa, \&T.E. Grift. 2006. Genetic evaluation of root complexity in maize. Acta Agro. Hungarica. 54(3):1-13.

Bosabalidis, A. M., \& Kofidis, G. 2002. Comparative effects of drought stress on leaf anatomy of two olive cultivars. Plant science, 163(2), 375-379.

Cahyono. B. 1998. Tomat, Budidaya dan Analisis Usaha Tani. Kanisius. Yogyakarta

Chmielowska-Bąk, J., Gzyl, J., RucińskaSobkowiak, R., Arasimowicz-Jelonek, M., Deckert, J., 2014. The new insights into cadmium sensing. Front. Plant Sci. 5, 245. doi:10.3389/fpls.2014.00245

Glick, B., R., Cheng, Z., Czarny, J., Duan, J. 2007.Promotion of plant growth by ACC deaminase-containing soil bacteria. Eur J Plant Pathol 119:329-339

Hussain. M, A., S.H. Wani., S. Bhattacharje., D.J. Burrit., L. Phan Tran. 2016. Drought Stress Tolerance in Plants, Vol 1. Physiology and Biochemistry. Springer. 1-17.

Jumawati, R., Sakya, A. T., \& Rahayu, M. 2014.
Pertumbuhan Tomat pada Frekuensi Pengairan yang Berbeda. Agrosains: Jurnal Penelitian Agronomi, 16(1), 13-18.

Jung, J. Y., Shin, R., \& Schachtman, D. P. 2009. Ethylene mediates response and tolerance to potassium deprivation in Arabidopsis. The Plant Cell, 21(2), 607-621.

Kamanga, R. M., Mbega, E., \& Ndakidemi, P. 2018. Drought tolerance mechanisms in plants: physiological responses associated with water deficit stress in Solanum lycopersicum. Adv. Crop Sci. Technol, 6(3), 1-8.

Klunkl, W., \& Savage, G. 2017. Effect on quality characteristics of tomatoes grown under well-watered and drought stress conditions. Foods, 6(8), 56.

Kulkarni. M., U. Deshpande. 2007. In vitro screening of tomato genotypes for drought resistance using polyethylene glycol. Afr. J. Biotechnol. 5 (16): 1488-1493.

Mishra, K. B., Iannacone, R., Petrozza, A., Mishra, A., Armentano, N., La Vecchia, G., Trtílek , M., Cellini, F., \& Nedbal, L. 2012. Engineered drought tolerance in tomato plants is reflected in chlorophyll fluorescence emission. Plant Science, 182, 79-86.

Ningrum, A. R., Nuraini, A., Suminar, E., \& Mubarok, S. 2020. Respons dua mutan tomat terhadap cekaman kekeringan. Kultivasi, 19(2), 1156-1161.

Okabe, Y., Asamizu, E., Saito, T., Matsukura, C., Ariizumi, T., Brès, C., Rothan, T., Mizoguchi T., \& Ezura, H. 2011. Tomato TILLING technology: development of a reverse genetics tool for the efficient isolation of mutants from Micro-Tom mutant libraries. Plant and cell physiology, 52(11), 1994-2005.

Poór, P., Kovács, J., Borbély, P., Takács, Z., Szepesi, Á., \& Tari, I. 2015. Salt stressinduced production of reactive oxygen-and nitrogen species and cell death in the ethylene receptor mutant Never ripe and wild type tomato roots. Plant Physiology and Biochemistry, 97, 313-322.

Pusat Pengkajian Perdagangan Dalam Negeri. 2019. Analisis Perkembangan Harga Bahan Pangan Pokok di Pasar Domestik dan Internasional.

Skirycz, A., Claeys, H., De Bodt, S., Oikawa, A., Shinoda, S., Andriankaja, M., ... \& Saito, K. 2011. Pause-and-stop: the effects of osmotic stress on cell proliferation during early leaf 
development in Arabidopsis and a role for ethylene signaling in cell cycle arrest. The Plant Cell, 23(5), 1876-1888.

Skirycz, A., De Bodt, S., Obata, T., De Clercq, I., Claeys, H., De Rycke, R., Andriankaja, M., Van Aken, O., Van Breusegem, F., Fernie, A.R., and Inze' , D. 2010. Developmental stage specificity and the role of mitochondrial metabolism in the response of Arabidopsis leaves to prolonged mild osmotic stress. Plant Physiol. 152: 226-244.

Streuter. A. 1980. Water potential of aqueous polyethylen glycol. Plant Physiol. 64(1): 6467.

Yuan, X. K., Yang, Z. Q., Li, Y. X., Liu, Q., \& Han, W. 2016. Effects of different levels of water stress on leaf photosynthetic characteristics and antioxidant enzyme activities of greenhouse tomato. Photosynthetica, $54(1), 28-39$. 